\title{
John Milner and the Orthodox Cause
}

\begin{abstract}
The study deals with Bishop John Milner, the English Catholic polemicist and historian, closely involved in affairs relating to the efforts to obtain Catholic emancipation. It identifies Milner's most fundamental concerns, offering a description of a coherent structure of anti-Enlightenment thought. This description serves to provide a unified interpretation both of his very varied and often influential writings and of his conduct in public affairs in England and Ireland. In this broad perspective, the figure of Milner can be seen to be important for an understanding of the transition being made in his period by the Catholicism of the British Isles to its nineteenthcentury identity.
\end{abstract}

In 1808 Bishop John Milner, who exercised jurisdiction over the Roman Catholics of England's Midland District and served as the agent of his Irish episcopal brethren in their dealings with politicians and public officials in England, ${ }^{1}$ expressed his distress at being plunged "over head and ears, into the tumultuous waves of Hibernian politics." 2 He had taken up his post as Catholic Ireland's ambassador in England with zeal. Ireland was important to him. Seeing in its Catholicism a greater militancy than that of his own English Catholic community, Milner looked to the Irish Catholics as a force. As he told his fellow countrymen: "they [the Irish] are the stately vessel which catches the breeze and stems the tide, we are the cock-boat which is towed in her wake."3 This conviction opened the way for an enthusiasm for all things Irish. Thus, to his new ambassadorial role he brought not only a knowledge of politics and politicians, but also considerable historical and literary talents,

1. Milner lacks a modern biographer. Reference should be made to the near contemporary, eulogistic work by F. C. Husenbeth, The Life of the Right Rev. John Milner . . . (Dublin: James Duffy, 1862). See also the pamphlet length study by Archbishop Maurice Couve de Murville, John Milner 1752-1826 ([Birmingham]: Archdiocese of Birmingham Historical Commission, 1986).

2. The Fourth Letter of Laicus, in Answer to Doctor Milner's "Appeal to the Catholics of Ireland" (Dublin: W. H. Tyrrell, 1809), 14.

3. J[ohn] Milner, Inquiry into Certain Vulgar Opinions concerning the Catholic Inhabitants and the Antiquities of Ireland. . . (London: Keating and Brown, 1808), 5.

C. D. A. Leighton is Associate Professor of History, Bilkent University, Ankara. 
which had been most notably manifested in his History of Winchester. These talents he had exercised in the task

of illustrating your [Irish] history and antiquities, of vindicating your apostle and ancient saints, of demonstrating the purity and truth of your religion, and of beating down the different adversaries who have risen up against it, of celebrating your national character, and more particularly, of defending your clergy and hierarchy, with all the divine rights and jurisdictions, to the best of my power ...

Now, however, he was being violently attacked as the Catholic nation's enemy, for plotting with the government to undermine the hierarchy. ${ }^{4}$ Milner's discomfiture was acute. For the immoderate abuse in the columns of the Evening Herald and the burning of his effigy in Dublin was occasioned by Milner's willingness to accept that the government might, in return for concessions, be allowed to exercise a degree of influence in the appointment of Catholic bishops. This was a view that had circulated for some decades and had, at times, been entertained by the episcopal bench. Milner was grieved at the accusation that he had misrepresented his Irish principals, but even more at the accusation that he had done so because he actually desired such government involvement in the affairs of the Catholic Church — an appropriate position for an English Cisalpine, but not for the Cisalpines' most consistent and effective enemy.

Milner's unpopularity among the Irish was neither deep nor enduring. Though the bishops, in September 1808, declared that Milner was wrong in his surmise that they would accept a government veto on Irish episcopal appointments, as a body, they took no great exception to his having expressed it. His eventual repudiation of Vetoism removed the cause of his unpopularity among the generality of Catholics. It was at least partly on account of his fervent campaigning against it that he was, only a few years later, "styled by them the 'Champion of Ireland'," as his Cisalpine enemy, Joseph Berington, recorded. ${ }^{5}$ However, Irish esteem for him did not rest solely on this stance. When Bishop William Coppinger of Cloyne and Ross, the most decided opponent of the veto on the episcopal bench, wrote an unsigned pamphlet in 1809 on the matter, he reproved Milner harshly, but also identified himself with his fellow countryman in praising "their truly learned favourite." Milner was thus celebrated, Coppinger wrote, by virtue of his zeal and skill as an anti-Protestant polemicist and, in particular, his authorship of Letters to a Prebendary. ${ }^{6}$ Coppinger's enthusiasm for Milner's controversial writings never diminished. He opined, in 1819, that Milner's definitive contribution to the field, the End of Religious Controversy, was a work "which every clergyman in the Empire should have as his daily exercise." " Nor was the Irish bishop alone in his expressions of admiration. Sir John Coxe Hippisley was an English

4. [John] Milner, Appeal to the Catholics of Ireland (Dublin: H. Fitzpatrick, 1809), 5, 7-8.

5. Berington to Rev. James Archer, 10 October 1813, Birmingham Archdiocesan Archive (hereafter BAA), St. Chad's Queensway, Birmingham, C series, no. 1981.

6. [William Coppinger], Royal Veto, on the Appointment of the Irish Roman Catholic Prelacy, Considered . . by an Irish Catholic Clergyman . . . (London: J. Booker, 1809), 5-7.

7. Coppinger to Milner, 28 January 1819, BAA, C series, no. 2298. 
parliamentarian whose opinions about what securities Catholics might give for admission to the constitution earned him Milner's deep hostility; but even as he disagreed with the bishop about the conduct of the relief campaign, he felt obliged, like Coppinger, to eulogize the controversialist as "no ordinary writer." The controversialist's works would "survive, when [those] . . . of your competitors, in your long polemic warfare, have sunk into oblivion." ${ }^{\text {"The }}$ prediction was accurate. Milner's Cisalpine opponents may have been right in criticizing his aggressive, wounding anti-Protestantism for being so much at variance with the spirit of the age; but that age was passing. Milner's militancy made him one of the most enduring and influential controversialists in a new era of controversy, ${ }^{9}$ while their eirenicism condemned them to oblivion.

Milner is chiefly recalled for the part he played in the politics of Catholic relief and emancipation between 1790 and his death in 1826. However, the present study is concerned to point out progressively that the bishop's political activity is well understood only when his orientations as a controversialist are also examined. These orientations, which may more properly be perceived as his dominant pastoral concerns, serve to illuminate much more than Milner's biography. They give indication too of the variant responses of Catholics in the British Isles to their environment in the late eighteenth and early nineteenth centuries. They also serve as guide to a mind, revealed in the entire body of Milner's writings, which, perhaps because it was not untypical of the period, aids a grasp of tendencies in the Catholicism of the British Isles in the nineteenth century and beyond.

In the history of Catholic relief and emancipation and, indeed it might be claimed, the history of modern Ireland, the events of 1808 were a turning point. The episcopal rejection of the veto in that year was the first clear step towards the Irish church's determination that it would enter into no institutional relationship with the British state. In Milner's personal history too, his difficulties in Ireland were a turning point. John Kirk, a clerical subject of the Midland District's vicar apostolic, was undoubtedly right, in large measure, in his claim that the later Milner's exaggerated reaction to any hint of concession to government and the consequent conflicts with and alienation from the leaders of the English Catholics, were attributable to his experiences in $1808-9 .{ }^{10}$ The present study, if its purposes are wider, may serve to give an explanation of the bishop's difficulties. A contemporary critic explained these by observing simply that Milner had become involved in the affairs of "a country with the

8. Globe, 8 May 1813

9. Milner's controversial works continued in circulation throughout the century. See, for example, Rev. Luke Rivington's edition of the End of Religious Controversy, published by the Catholic Truth Society in London in 1896. Useful sections were likely to be published separately as cheap or free tracts. See note 82 below.

10. John Kirk, Biographies of English Catholics in the Eighteenth Century, ed. John Hungerford Pollen and Edwin Burton. (London: Burns and Oates, 1909), 164. 
dispositions and prejudices of whose inhabitants he ... [was] not sufficiently acquainted." 11 However, the matter may be put more exactly. Milner had long, as an English priest and bishop, had to cope with a number of intellectual, religious, and political problems associated with a phenomenon we denominate as Gallicanism. He failed to observe, however, that this phenomenon had not extended to Ireland without mutation. Comment on this failure may clarify the use of the term in speaking of the British Isles. It may also give a better understanding of Milner's mind.

In his role in contemporary politics, Milner consistently placed the advancement of Catholicism before the advancement of Catholics. He thus certainly thought his work as an apologist more important than his participation in public affairs. His fine historical work too, he placed on a lower level of seriousness. ${ }^{12}$ However, all of his work possessed a unity and it is a chief object of this paper to indicate in what this consisted. Milner had a cast of mind that led him constantly to seek the underlying principles of what he heard and read. Berington, who had reason be nervous of it, was anxious to depict this as a manifestation of the mind of the inquisitor at work on the detection of imaginary heresy.

In the indulgence of his restless passion [for controversy], he has always some game on foot: Blanchardism, or O'Conorism, or Blue-bookism, or Charles-Butlerism, or Dillonism. The brain of the Knight of La Mancha was not more disturbed by phantoms. ${ }^{13}$

However, the bishop would also have conceded the existence of "Milnerism"; for he was apt to speak of "my system." This existed for the service of what he generally referred to as "the orthodox cause." ${ }^{\prime 4}$ The meaning of this can be somewhat clarified with an indication of its antithesis. When Milner commented on an intended episcopal censure of Sir John Throckmorton, whom he had taken as his chief opponent in the debates of the early 1790s, he indicated his own adherence to the Catholic Church's pastoral purposes, as he explained:

I do not mean that it is advisable to censure each particular position; but, if his system is reducible to certain heads, as I am persuaded it is, and those heads are precisely the prevailing errors of the times, the same which have taken root in more breasts than that of Sir John, I think the business [of the censure] will be done imperfectly, if any one of the sources of error is left open to infect the public orthodoxy. ${ }^{15}$

11. Inimicus Veto, The Present State of Catholic Affairs in Ireland Considered... (Dublin: Richard Coyne, 1808), 19.

12. John Milner, A Treatise on the Ecclesiastical Architecture of England, during the Middle Ages ... (London: J. Taylor, 1811), x.

13. A copy of a letter by Berington to the editor of the Orthodox Journal in Berington to Archer, 10 October 1813, BAA, C series, no. 1981.

14. See, for example, Milner to Fr. Charles Plowden, 29 November 1791 and 19 November 1791, Archivum Britannicum Societatis Iesu (hereafter ABSI), Mount Street, London, W1, Milner Correspondence, 1: $84 \mathrm{v}$ and $80 \mathrm{r}$.

15. Milner to Plowden, [the latter part of 1792], ABSI, Milner Correspondence, 1: 117r. 
To state the matter briefly, Milner's works should be read as a consistent refutation of the Enlightenment, "the prevailing errors of the times", and his actions interpreted in the light of his desire to combat their effects. Any acquaintance with the contemporary historiography of the Enlightenment will raise the question of whether intellectual trends so diverse, in so many fields, so capable of unification with contrary trends and so closely bound to social developments was capable of receiving a consistent refutation. If Milner's own viewpoint is adopted, ${ }^{16}$ this hardly constitutes a difficulty. What he opposed had a clearly defined character. He was intensely conscious of the Enlightenment described by Burke, as well as much lesser conspiracy theorists, such as the French priest, Augustin Barruel, and the Scottish professor, John Robison: "that Anti-Christian conspiracy on the continent" which culminated in the French Revolution. ${ }^{17}$ Further, his habitual inclination to seek the wellsprings of error enabled him to focus on the question which historians of philosophy have conventionally identified as central to the Enlightenment/ Counter-Enlightenment debate — about the epistemological location of authority. As Justin Champion has pointed out, ${ }^{18}$ this question was not separable from questions about the institutional location of authority. This rendered Enlightenment/Counter-Enlightenment debates, at least for Milner, a development of the Reformation era's debates about authority. To some extent, Milner was happy simply to use the Enlightenment as anti-Protestant polemic: the evil of Protestantism's implicit or explicit claims to a right of private judgement in matters of religion was now manifest. However, to a greater extent, he attempted to re-orientate Catholic apologetic towards an attack on the Enlightenment itself. The point is made particularly clear in Milner's treatment of the pre-eminent rationalist challenge to Anglican, but not Catholic, ecclesiastical authority in the eighteenth century - the anti-trinitarianism of Arians and Socinians. ${ }^{19}$ Newman's reference to Milner as "the English Athanasius" 20 should be read as praise not merely of the vicar apostolic's stance as a solus contra mundum in his protracted conflict with his English co-religionists or of his defence of orthodoxy in general. It is a reference precisely to his hatred of

16. What Milner identified as "the prevailing errors of the times" can be quickly perceived in his Funeral Oration on His Late Most Christian Majesty Louis XVI . . . (London: J. P. Coghlan, [1793]), 16-39.

17. J[ohn] M[ilner], The End of Religious Controversy: In a Friendly Correspondence between a Religious Society of Protestants and a Roman Catholic Divine . . , $5^{\text {th }}$ ed. (London: Keating and Brown, 1824), ii.

18. J. A. I. Champion, The Pillars of Priestcraft Shaken: The Church of England and its Enemies 1660-1730 (Cambridge: Cambridge University Press), 10.

19. J. Redwood, Reason, Ridicule and Religion: The Age of Enlightenment in England 16601750, 2 d ed. (London: Thames and Hudson, 1996), ch. 7; M. Wiles, Archetypal Heresy: Arianism through the Centuries (Oxford: Clarendon Press, 1996), ch. 4. See especially pp. 158-60. J. I. Israel, Enlightenment Contested: Philosophy, Modernity, and the Emancipation of Man 16701752 (Oxford: Oxford University Press, 2006), ch. 5.

20. W. Ward, The Life of John Henry Cardinal Newman ... (London: Longmans and Green, 1912), 1: 119. The comparison occurred to others, including Milner himself. See Husenbeth, Life of the Right Rev. John Milner, 196, 529 and John Milner, Letters to a Prebendary . .., 2d ed. (Winchester: Robbins, 1801), 505-6. 
anti-trinitarian heresy, the chief characteristic of the English Enlightenment, in effective combat with which, Newman and Milner were comrades in arms. $^{21}$

Milner entered his Irish controversy of 1808-9 with an anti-Gallican stance formed chiefly, but not exclusively, by English events and attitudes. Pre-eminent among the former was the conflict at about the time of the relief bill of 1791, over the oath it incorporated. ${ }^{22}$ However, Milner conducted this combat while constantly observing events on the other side of the Channel. He entered it with a consciousness of how dangerous the foe he was to face had become. The Synod of Pistoia, he observed, had little to do with Jansenism. Its spirit, now clearly to be seen in England, sprang from the Enlightenment - referred to, by synecdoche, as "irreligion" and "deism." 23 In the controversy with Throckmorton, Milner lost no opportunity to expatiate on the disasters which had overtaken the French church, as a consequence of the Civil Constitution of the Clergy.

The depiction of Milner as chiefly engaged in a struggle against aristocratic predominance in the English Catholic body ${ }^{24}$ is perhaps responsible for the suggestion that his identification of his English opponents with the revolutionaries who framed the Civil Constitution was little more than a smear tactic. ${ }^{25}$ His opponents were improbable Jacobins. It is true that Milner found himself a champion of the authority of the episcopate against that of the traditional lay leadership. However, this came about accidentally. Had these leaders not been "deceived, both as to facts and doctrine, by their lawyers and divines"26 into supporting views so obnoxious and so threatening to existing ecclesiastical authority, Milner would hardly have taken it upon himself to oppose them. The difficulties he faced in Ireland in 1808 sprang, in part, from his adherence to the aristocratic party there — a quite consistent adherence since the

21. Robert Pattison makes clear the importance of Arianism in forming Newman's critique of characteristically modern thought. Regrettably though, Pattison seems unaware of the central role of anti-Trinitarianism in the history of the English Enlightenment and thus perceives Newman as singular in his concern with this topic. See R. Pattison, The Great Dissent: John Henry Newman and the Liberal Heresy (Oxford: Oxford University Press, 1991). See especially pp. 100-104.

22. The writings of Bernard Ward continue to give an indispensable narrative of this and other events mentioned in this study. See The Dawn of Catholic Emancipation in England 1781-1803, 2 vols. (London: Longmans and Green, 1909) and The Eve of Catholic Emancipation, 3 vols. (London: Longmans and Green, 1911). Ward describes the conflicts of the early 1790s in the latter part of the first volume of the former work. See also E. Duffy, "Ecclesiastical Democracy Detected," parts 1-3, Recusant History 10 (October 1970): 309-31.

23. Milner to Plowden, 15 May 1790, ABSI, Milner Correspondence, 1: 3. For a brief account of the synod, see O. Chadwick, The Popes and European Revolution, Oxford History of the Christian Church (Oxford: Clarendon Press, 1981), 424-31.

24. J. Bossy, The English Catholic Community 1570-1850 (London: Darton, Longman and Todd, 1975), 334-37.

25. Couve de Murville, John Milner, 23.

26. J[ohn] M[ilner], Supplementary Memoirs of English Catholics ... (London: Keating and Brown, 1820), viii. 
famous Kenmare Schism among Catholic activists in 1791. ${ }^{27}$ In England, when the Cisalpines ${ }^{28}$ had been beaten and a satisfactory act and oath obtained in 1791, Milner noted that it was the laymen who had been the most potent and effective enemy. Nevertheless, he pleaded "for moderation and tenderness" in dealing with them. Their clerical ideologues, on the other hand, "deserve[d] no mercy."29

The identification of the Cisalpines with the French revolutionary ecclesiastical reformers and the accusation of democracy were not merely smears, but Milner's fundamental motivation in engaging in the conflict. He made the identification in his usual way, seeking out common fundamental principles. His English opponents had

adopt[ed] those very principles which have subverted the foundations of ... [the French] church, and laid it open to all the horrors of modern innovation: for, in that poisonous mass of schism and heresy called the civil constitution of the clergy of France, the most deadly ingredient, as all divines allow, is that which relates to the appointment and jurisdiction of bishops, and it were easy to shew how from this one evil all the rest have flowed. ${ }^{30}$

Milner's identification of the English Cisalpines with French revolutionaries may appear far-fetched; but it is defensible. For the history of the Civil Constitution of the Clergy should not be read in the light of the fate of the Constitutional Church. The framers of the Civil Constitution sincerely intended a reform in the Gallican tradition, which would give the church a role in the new society, and not an assault. ${ }^{31}$ Indeed, the Cisalpines went somewhat beyond their French counterparts in their inclination to democratic practices.

It is of consequence to note what Milner understood by the term, when he accused his opponents of advocating "democracy." Certainly he perceived it, in its flowering, as a subversion of ecclesiastical structures, divinely established on "monarchical and aristocratical principles." subverted the authority of the pope to the advantage of the bishops, the authority of the bishops to the advantage of the lower clergy, and the authority of the whole clerical body to the advantage of the laity. However, Milner penetrated below this discussion of ecclesiology. It was not "only the rule of discipline, but also that of faith" which Throckmorton sought to subvert. For he claimed "for the laity the same right ... of judging of faith with the clergy

27. Milner to Plowden, [early 1792], ABSI, Milner Correspondence, 1: 91r. For the Kenmare Schism, see T. Bartlett, The Fall and Rise of the Irish Nation: The Catholic Question 1690-1830 (Dublin: Gill and Macmillan, 1992), 128-31.

28. The use of this term is proleptic here. The Cisalpine Club was not formed until April 1792.

29. Milner to Plowden, 10 and 19 October [1792], ABSI, Milner Correspondence, 1: 75r and 76v.

30. John Milner, The Divine Right of Episcopacy . . in Answer to the Layman's Second Letter to the Catholic Clergy of England... (London: J. P. Coghlan, 1791), 7. Cf. John Milner, A Serious Expostulation with the Rev. Joseph Berington upon his Theological Errors . . (London: J. P. Coghlan, 1797), 64-65.

31. N. Ravitch, The Catholic Church and the French Nation 1589-1989 (London: Routledge, 1990), 51-59.

32. John Milner, Ecclesiastical Democracy Detected: Being a Review of the Controversy between the Layman and the Clergyman Concerning the Appointment of Bishops . . (London: J. P. Coghlan, 1793), 1. 
of any description." 33 The accusation of democracy is to be found elsewhere in Milner's writings, directed, this time, against the early eighteenth-century Anglican bishop, Benjamin Hoadly. It was, in part, founded on the bishop's adherence to the Whig principles now being used to justify a new revolution; but it rested far more on the disclosure of the ultimate explanation of his Whiggery. He intended

to make all power, ecclesiastical as well as civil, centre in the people; and by destroying all pretensions in the pastors to any degree of authority from Christ, to found a mere philosophic system of natural religion, such as Hoadlyism actually is.

Hoadly's natural religion was specified more exactly, as Arianism. ${ }^{34}$

Milner fought against Cisalpinism because he recognized in it the Enlightenment - the ideology of the French Revolution, founded on individualistic rationalism and therefore inevitably inclined to heterodoxy. However, hostility to Cisalpinism did not necessarily mean a rejection of all Gallicanism. Milner is better described as a Counter-Enlightenment figure than as an Ultramontanist. If in many ways Milner anticipated the nineteenth century, his mind was nevertheless formed in the eighteenth. He justified the practice of allowing deans and chapters or princes to nominate to the episcopate, while insisting, of course, that the right of canonical institution remain with the Holy See. Further, he explicitly declined to state an opinion on the claim, made by Pius VI in a brief of 1791, that this right was inherent in the Holy See. ${ }^{35}$ With regard to the British Isles, he expressed contentment with the existing system of making episcopal appointments, since, in practice, it left nomination in the hands of the existing prelates. ${ }^{36}$ However, before his Irish misadventure, he took no serious exception to King George's influence over nominations exercised in Canada and, briefly, in Corsica — being extended to more important parts of his dominions. ${ }^{37}$

Much of the social foundation of Gallican opinion and politics in the British Isles lay in the desire of Catholics for assimilation. Variation arose from a diversity of views about the society to which they were to be assimilated. English Cisalpines, with their flirtations with heterodox dissent and radicalism, reveal one such set of views. Others were better disposed to the established order. The desire for acceptance within it permitted proposals for government involvement in Catholic affairs, intended to assuage anti-Catholic belief, to be construed as the opportunity to create a subordinate religious establishment. Such a cast of mind was likely to manifest itself, when it viewed the state's political aspect, in political loyalism and hostility to radicalism and, when it

33. Milner, Ecclesiastical Democracy, 146-55.

34. Milner, Letters to a Prebendary, 424, 457-59.

35. Milner, Divine Right of Episcopacy, 29-33, 42-44 and his Ecclesiastical Democracy, 15

36. Milner, Divine Right of Episcopacy, 36-37. See also Milner to Bishop John Douglass, 13 February 1799, Archives of the Archdiocese of Westminster (hereafter AAW), Abingdon Road, London, W8, Douglass Papers, vol. A53, file IIIb.

37. [John Milner], The Case of Conscience Solved: Or Catholic Emancipation Proved to be Compatible with the Coronation Oath ... (London: R. Faulder, 1801), 22. J[ohn] Milner, A Short View of the Chief Arguments against the Catholic Petition now before Parliament . . (Dublin: H. Fitzpatrick, 1805), 10, 47. 
viewed its ecclesiastical aspect, in identification with the established church and hostility to Dissent. This disposition was not uncommon in Ireland, where, probably, its most notable representative was Archbishop Butler of Cashel. He was labelled by John Troy, then bishop of Ossory, as one of $i$ capi Gallicani ${ }^{38}$ but his Gallican sentiments gave him no inclination to support the English Cisalpines. ${ }^{39}$ Very numerous passages in his writings might be cited to display the earlier Milner as at least close to this establishmentarian Gallicanism. However, Peter Nockles, referring to some of the most striking of such passages, has recently emphasized that Milner's loyalism and identification with high churchmanship in its struggle against Latitudinarianism was a tactical matter. ${ }^{40}$ The intent was to engender sympathy for Catholicism in an era of triumphant, if fearful, conservatism. Full weight should be given to Nockles's argument. However, it would certainly be wrong to believe that Milner was doing no more than creating a rhetorical strategy when he, for example, attacked "Hoadlyism." It is true that he acknowledged in private that it was "not ... for the cause of the establishment" that he was solicitous; but the cause of Catholicism did concern him. This, he knew, was bound up with "the general cause of peace, humanity and Christianity, ${ }^{, 41}$ which was in imminent danger from those inspired by the Enlightenment principles, of which Hoadly was one of the most prominent English articulators.

So much may be said of Milner's positions in the 1790s. Then, to a degree not matched before or after, the Catholic Church, the victim of the revolutionary tyranny, found sympathy in unlikely Anglican quarters and Catholic loyalism earned the smiles of government. Milner himself established a particularly good relationship with Bishop Samuel Horsley and had obtained valuable support from him in his struggles against the Cisalpines in 1791 and again in the matter of a proposed piece of anti-Catholic legislation in $1800 .{ }^{42} \mathrm{He}$ also found favour in government circles, where the radical inclinations of his Cisalpine enemies were noted. ${ }^{43}$ The atmosphere of the following decade was very different. The French Concordat and the failure of Pitt to carry the fuller admission of Catholics to the constitution were the pre-eminent events which precipitated an end to a thaw in relations between the British establishment and Catholicism, which was not, in any case, likely to continue. ${ }^{44}$ In his Case

38. C. D. A. Leighton, Catholicism in a Protestant Kingdom: A Study of the Irish Ancien Régime (London: Macmillan, 1994), ch. 8.

39. Milner to Plowden, 15 May 1790, ABSI, Milner Correspondence, 1: 3v. Note also Milner's praise of him and Fr. Arthur O'Leary, who held similar views, in his Catholic Inhabitants of Ireland, 15, 16.

40. P. Nockles, “' 'The Difficulties of Protestantism': Bishop Milner, John Fletcher and Catholic Apologetic against the Church of England in the Era from the First Relief Act to Emancipation, 1778-1830," Recusant History 24 (October 1998): 197-211.

41. Milner to Plowden, 5 November 1791 and [6 January 1792], ABSI, Milner Correspondence, 1: $78 \mathrm{v}$ and 86 .

42. F. C. Mather, High Church Prophet: Bishop Samuel Horsley ... and the Caroline Tradition in the Later Georgian Church (Oxford: Clarendon Press, 1992), 95-112.

43. See, for example, Milner to Douglass, 29 August 1793 and Plowden to Douglass, 29 August 1793, AAW, Douglass Papers, vol. A45, 202v and 203v.

44. J. J. Sack, From Jacobite to Conservative: Reaction and Orthodoxy in Britain, c. 1760 1832 (Cambridge: Cambridge University Press, 1993), 227-51. 
of Conscience Solved, Milner recorded his dismay at both the departure of Pitt's government, well disposed to Catholic emancipation, and the cause of that change, the position taken by the king, ${ }^{45}$ but, even before that, he had been made aware that favourable dispositions towards Catholicism were waning. For it was in Winchester, Milner's own mission and the English home of so many émigré clergy, that the anti-Catholic proposals of 1800 originated.

It may be, therefore, that Milner entered his Irish conflicts with a diminished optimism about the relationship between the Catholic Church and the British state. However, his attitudes were fundamentally those that had served him in the previous decade. He entertained a confidence in the British political establishment, founded on good personal relations with a number of its members. Concessions might be made to such men, provided they did not seriously threaten episcopal authority and gave no support to the Enlightenmentinspired principles of the Cisalpines. To the aristocratic party in Ireland, led by the earl of Fingall and disposed to concede a veto, Milner was well inclined. They had stood against those tainted with revolutionary principles in the 1790s. More importantly, unlike their English counter-parts, they were very little apt to adopt or support intellectual stances dangerous to the cause of orthodoxy. The only notable articulator of their views, Theobald McKenna, lacked any serious interest in religion, perceiving it chiefly as an instrument for social control and amelioration. His proposals for placing this instrument in the hands of government were clearly unacceptable to Milner; but no one could have detected ecclesiastical democracy in them. ${ }^{46}$ In brief, Milner had no reason for serious opposition to the proposed veto: the concession was not to Enlightenment heterodoxy.

Milner would have done well to accept wholeheartedly and at once the bishops' rejection of the veto. An expression of regret for his error would have saved him much trouble. He did urge obedience to the bishops, insisting that it was "for them, and them exclusively, to decide upon the expediency of the measure." However, he also insisted that he had not been wrong to indicate that a veto could be accepted and, in addition, made very complimentary remarks about the leading members of the Irish aristocratic party. ${ }^{47}$ All of this was provocative. Initial hostility to the veto appears to have been generated chiefly by hostility to the aristocratic party ${ }^{48}$ and with this party the bishops had, in the past, been disposed to side, ${ }^{49}$ even if, for the moment, they had diverged from its views. However, the politics of the matter were more complex than this. Those who disliked the earl and his friends had found a

45. [Milner], Case of Conscience. See especially pp. 6-7.

46. C. D. A. Leighton, "Gallicanism and the Veto Controversy: church, state and Catholic community in early nineteenth-century Ireland," in Religion, Conflict and Coexistence in Ireland: Essays Presented to Monsignor Patrick J. Corish, ed. by R. V. Comerford et al. (Dublin: Gill and Macmillan, 1990), 140-43.

47. Milner, Appeal to the Catholics. See especially pp. 15-16, 21.

48. Leighton, "Gallicanism," 137.

49. D. Keogh, "Christian Citizens: The Catholic Church and Radical Politics 1790-1800," in Protestant, Catholic and Dissenter: The Clergy and 1798, ed. L. Swords (Blackrock, Co. Dublin: Columba Press, 1997), 9-18 passim. 
good issue. Burke had long before pointed out that government involvement in Catholic ecclesiastical appointments would mean, in practice, local Protestant interference. Burke's observation was frequently recalled in the course of the veto controversy. ${ }^{50}$ Neither Catholic laymen concerned with national or local politics, nor the lower clergy, nor the bishops were willing to let this proposed intrusion into what they regarded as their own domain go unchallenged. The interplay of these groups in response to parliamentarians' demands for securities produced a complex struggle, which was to continue into the $1820 \mathrm{~s}^{51}$

Ireland was not devoid of opinions that can be described as Gallican. At least, concern for the interests of the Holy See decidedly came after concern with the advancement of various Irish interests. Further, the French emperor's policy with regard to the papacy and his treatment of Pius VII, as well as the beliefs of British politicians, made some diminution in Roman involvement in Irish affairs appear inevitable. However, these were matters of politics, domestic or European, not of principle. It is true that English Gallicanism had its origins chiefly in the political matter of emancipation and was influenced by the affairs of all Europe; but the internal politics of the Catholic community were not, as in the case of Ireland, its driving force and central concern. From political circumstances, there arose in England an intellectual movement, which Ireland lacked. It displayed little profundity; but it was capable, for a time, of influencing Catholic affairs and it is the primary referent of the term "English Gallicanism." It was certainly so for Milner. That he did not misjudge the character of what he struggled against is vouched for by its protagonists' willingness to acknowledge him as their chief enemy. ${ }^{52}$ If initially he lacked a similar clear understanding of Irish matters, his experiences in 1808-9 served to instruct him.

His assertion of the falsity of the core doctrines of the Enlightenment and insistence that adherence to them constituted immorality, has been judged to raise Newman from the sphere of ecclesiastical politics and theology to that of cultural criticism. Newman may indeed be read in this way; but so may the greater part of the intellectual history of the Catholic Church - and, for that matter, other Christian bodies - in the nineteenth and twentieth centuries. ${ }^{53}$ Milner's fundamental intellectual stance, then, was by no means singular: it

50. See, for example, [Coppinger], Royal Veto, 9.

51. Leighton, "Gallicanism," 143-58.

52. Milner to Plowden, 6 April [1791], ABSI, Milner Correspondence, 1: 60v indicates that the Cisalpines found Fr. Charles Plowden, the Jesuit chaplain to the Weld family of Lulworth, equally obnoxious. Plowden, however, was lost to Milner as an active ally, when he did not follow him to the midlands. See Milner to Plowden, [before 10 June 1811], ABSI, Milner Correspondence, $2: 31 \mathrm{v}$.

53. This reading of Newman has been advanced in Pattison, Great Dissent. The comment here on the normality of such a stance is offered as further criticism (see note 21 above) of this most useful contribution to Newman studies. 
was no more than an expression of a normative Catholic position. This, as just suggested, is more than worthy of discussion; but so is Milner's distinctive expression of it. If his stance is most easily described in a simple, negative way, it nevertheless found positive and fruitful expression in varied subject matter. Of interest in itself, it is also a noteworthy part of the history the distinctively English tradition of thought shaped in reaction to the Enlightenment.

The variety of Milner's subject matter was, in part, involuntary: it was the consequence of involvement in the changing world of public affairs. Though constrained to turn his mind to the Catholic question, he found opportunity here too for anti-Enlightenment polemic. That there was a need to conciliate Catholics when foreign danger threatened, was an old argument in Catholic relief literature; but now the threat came from "an Anti-christian association... [which was] with gigantic strides, march[ing] in triumph throughout the greatest part of the civilized world, everywhere marking its progress with the ruins of Christian altars." 54 Again, the common Protestant assertion that the Catholic doctrine of exclusive salvation precluded sincere acceptance of the British constitution might have been answered with eirenic language, as it had been in the past. Instead, Milner chose to take his stand on the creeds, subscription to which had been the chief affliction of rationalist, heterodox Christians throughout the eighteenth century - not least because they did teach the doctrine of exclusive salvation. Thus, this was a matter of fundamental Christian dogma, common to Catholic and Anglican alike. ${ }^{55}$ However, it is not merely such incidental, if very frequent, expressions of hostility to the Enlightenment that reveal Milner's true concerns, as he wrote on Catholic politics. Rather, it is his warnings that the orthodox cause could not be disadvantaged by the pursuit of the relatively unimportant goal of emancipation — "the permission of a mere handful of Irish and English Catholics of rank and fortune to take their chance of getting into Parliament or office." $" 56$ As his hostility to the veto hardened after 1808, Milner felt increasingly obliged to warn Catholics against "submitting to religious bondage in exchange for civil liberty." 57 For his Jesuit friends he elucidated the nature of this bondage. Identifying Hippisley as the chief proponent of the veto, he explained that

he and his party are ... bent on our submitting to all the Jansenistical and deistical tyranny which has been imposed upon Cath[olic]s in ... [every] nation on the Continent, and you will easily discover that he aims at being our Ministre du Culte. ${ }^{58}$

Milner had also come to share the Irish fear that power over the Catholic Church would lie in the hands of men outside government. However, while the Irish feared the influence of the lesser members of the Protestant ascendancy,

54. [Milner], Case of Conscience, 29.

55. Milner, Chief Arguments, 12.

56. Milner, Chief Arguments, 41

57. J[ohn] Milner, An Elucidation of the Veto: In a Threefold Address to the Public, the Catholics, and the Advocates of Catholics in Parliament (London: Keating and Brown, 1810), 28. See also M[ilner], Supplementary Memoirs, 1.

58. Milner to Plowden, 19 November [1810], ABSI, Milner Correspondence, 2: 30r. 
Milner feared the heterodox. The design of Hippisley and his party, he was convinced, was to "lay our holy religion under the feet of Socinian parsons."

Milner's historical writings and particularly those on the history of architecture have been praised, though perhaps insufficiently. While celebrated contemporaries, like Sir James Hall, produced the most curious speculations about the origins of the Gothic style ${ }^{60}$ Milner articulated the view accepted by Thomas Rickman and the later Gothicists and went on to assist them further with a sound periodization. ${ }^{61}$ As he deserves to be taken seriously as an historian of architecture, equally he merits regard as a mediaevalist, rather than as a mere antiquarian. About mere antiquarians, Milner was slighting. His concern, in contrast, was with "the most excellent branch of ancient learning ... ancient manners and virtues." ${ }^{\prime 62}$ These were of consequence, since they reflected the teachings of the mediaeval church and vindicated them by their superiority over modern mores, which revealed only "vice and incredulity." ${ }^{93}$ Milner's disgust at his own Enlightened age, indicated too by his acknowledgements that he was incapable of gaining its approval,${ }^{64}$ had its positive complement in the depiction of a spiritually, morally and intellectually superior age. Such depiction, at least in essentials, already existed: ancient churches declared Catholic teachings. They were thus to be preserved in such a way that they could do so clearly. ${ }^{65}$ A new church in the old style might do the same; and so Milner built the first church of the Gothic revival, St. Peter's in Winchester. ${ }^{66}$ This building was a three dimensional illustration of what chiefly he sought to convey in the loving, period by period and almost stone by stone reconstruction of mediaeval Winchester in the History.

Milner the scholar was stunted, chiefly by his vocation as a pastor. Placing this before scholarship, he chose to work in a minor field of mediaeval studies, which can still be confused with antiquarianism. He therefore lacked that immersion in the thought of the past characteristic of Newman (in this case the thought of the patristic period), which enabled this more profound thinker to contend so effectively and in a positive manner with the continuing influence of the Enlightenment in the nineteenth century. Milner the pastor, when not absorbed by the quotidian duties of the priest and bishop, was confined to the

59. Milner to Fr. Joseph Dunn, 29 June [1811?], ABSI, Milner Correspondence, 2: 33v.

60. For the opinions about the origins of Gothic against which Milner contended against, see his Ecclesiastical Architecture, ch. 4. See also C. Stewart, Gothic Architecture, vol. 3 of Simpson's History of Architectural Development, 2d ed. (London: Longmans and Green, 1961), 3-5.

61. For Rickman's acceptance of Milner's view that that the Gothic style had evolved from Romanesque, see Thomas Rickman, An Attempt to Discriminate the Styles of English Architecture ... (London: Longman, Hurst, Rees, Orme and Brown, [1819]), 37-38. With regard to periodisation, cf. Rickman, Attempt to Discriminate, 39, 44 and Milner, Ecclesiastical Architecture, ch. $6-8$.

62. John Milner, The History Civil and Ecclesiastical and Survey of the Antiquities of Winchester (Winchester: James Robbin, 1798), 1: 3.

63. J[ohn] M[ilner], Authentic Documents Relating to the Miraculous Cure of Winefrid White... (London: Keating and Brown, 1805), 23.

64. See, for example, Milner, Divine Right of Episcopacy, ii-iv and John Milner, trans., Exclamations of the Soul to God ... , by Teresa [of Avila] (London: J. P. Coghlan, 1790), xvii. 65. John Milner, A Dissertation on the Modern Style of Altering Ancient Cathedrals ... (London: J. Nichols, 1798).

66. He explained its symbolism at length in the History of Winchester, 2: 229-48. 
negative task of repelling immediate dangers. The nature of these dangers may, at first, appear to be varied. The tracts on the miraculous, $A$ Serious Expostulation with Joseph Berington and the Miraculous Cure of Winefrid White are easily classified as continuations of well-known debates between the protagonists and antagonists of Enlightenment ideas. Berington, in response to reports of miraculous events in Italy, had rehashed the views of Conyers Middleton. Milner rehearsed the arguments with which Middleton had been met: undue scepticism about the miraculous outside the biblical narrative undermined that within it. ${ }^{67}$ Characteristically, though, Milner reverted a good deal to the crucial matter of authority. Berington's true target, his antagonist emphasized, was not the miraculous, but rather the ecclesiastical authority which it supported. ${ }^{68}$

Milner's reputation as an anti-Protestant polemicist may suggest that he was, at times, diverted into older debates than those of the Enlightenment era; but this is not so. The Protestantism he attacked was less that of the Reformation - though here was the original, undeveloped form of the evil — than that which had, at length but inevitably, become visible. Protestantism had grown, by virtue of the kind of seed it was, into either a rationalist or an enthusiastic religion. Milner's chief work of anti-Protestant polemic, the End of Religious Controversy, sought to show how this development had occurred. What this drew attention to were the fundamental epistemological disagreements in Enlightenment/Counter-Enlightenment argumentation, in its English manifestation. As he read Bossuet's History of the Variations, Milner reflected on the eighteenth-century Church of England, its enemies and its compromises. ${ }^{69}$ It was England that was of concern; for it had been proved "that the poisonous plant of infidelity, which has produced such dreadful effects of late years on the Continent, was transplanted thither from this Protestant island."70

The End of Religious Controversy isolated erroneous epistemological stances which lay at the heart of this debate. In Protestant England, Enlightenment rationalism had predominantly taken the form of an assertion of the right of private judgement in the interpretation of scripture. After all, even the most heterodox maintained that they were engaged in a defence of Protestant Christianity. Milner, well acquainted with orthodox Anglican divinity, acknowledged the dilemma in which this had placed many, hostile to Enlightenment rationalism, but unwilling to abandon a Protestant principle. They were consequently "obliged to say and unsay, to the amusement of some persons and the pity of others." "I1 In urging them simply to abandon this rationalist position, he pointed to the impossibility of its achieving its object: scripture would inevitably be interpreted in the light of pre-existing creeds and prejudices. $^{72}$ The later Milner spoke with increasing bluntness of the effects

67. Milner, Expostulation with Berington, 57-61

68. Milner, Expostulation with Berington. See especially pp. 72-85.

69. Undated note by John Milner, BAA, C series, no. 1681.

70. M[ilner], End of Religious Controversy, 61.

71. M[ilner], End of Religious Controversy, 66.

72. M[ilner], End of Religious Controversy, 57-78. 
which the creeds and prejudices of the Enlightened were exercising on the Church of England. In addressing the poet laureate, Robert Southey, he told him that "the majority of your clergy ... are not Christians, and would have been burnt at the stake by Cranmer and Ridley, had they lived in their days." ${ }^{173}$ Nockles points to the tactical value this had, as High Church apologists sought to offer the apostolic authority of the Church of England as an alternative to that of the Roman Church. ${ }^{74}$ However, an understanding of Milner is better served by emphasizing that such an approach was far more than merely tactical.

Eighteenth-century Anglican hostility to Enlightenment rationalism took various forms. Some, like the Hutchinsonians, attempted to meet the enemy on their own ground, believing that scripture remained a position from which trinitarian orthodoxy could be defended..$^{75}$ Milner, while unwilling to state plainly that this was untrue, made very clear the difficulty of such a belief. ${ }^{76}$ Others, such as the William Law, after his adoption of Behmenism, ${ }^{77}$ and, at times, other Nonjurors ${ }^{78}$ had sought epistemological certainty in divine illumination. Milner's refutation of enthusiasm included historical reference to the enormities of those who claimed divine inspiration; but he was equally concerned to show its close association with individualistic rationalism. His exemplifications of enthusiasm were chiefly drawn from the post-Reformation period and depicted as the products of the reformers' assertion of the right of private judgement. In any case, enthusiasm and Enlightenment rationalism had the same outcome: the reduction of dogmatic statements to the level of opinion. $^{79}$

All this, of course, was intended to prepare the way for the exposition of the "right rule of faith": truth was obtained from the scripture and tradition of an infallible church ${ }^{80}$ It remained only to establish that that subsisted in the Roman Church. ${ }^{81}$ Milner, as the title of his book indicates, considered this shift to epistemological discussion constituted an important development in religious controversy. ${ }^{82}$ True, discussion of the rule of faith was a conventional

73. John Milner [John Merlin, pseud.], Strictures on the Poet Laureate's "Book of the Church" (London: Keating and Brown, 1824), 86.

74. Nockles, "Difficulties of Protestantism,"” 211-18.

75. C. D. A. Leighton, “'Knowledge of Divine Things': A Study of Hutchinsonianism," History of European Ideas 26 (2000): 159-75.

76. M[ilner], End of Religious Controversy, 75.

77. C. D. A. Leighton, "William Law, Behmenism and Counter-Enlightenment," Harvard Theological Review 91, no. 3 (July 1998), 301-20.

78. C. D. A. Leighton, "The Nonjurors and the Counter Enlightenment: Some Illustration," Journal of Religious History 22, no. 3 (October 1998): 285-86. The inclination to enthusiasm was very marked among their Scottish brethren, among whom there was, for example, a strong interest in the Camisard Prophets. See G. D. Henderson, ed., Mystics of the North East: Including . . Correspondence between Dr. George Garden and James Cunningham (Aberdeen: Third Spalding Club, 1934), 191-262.

79. M[ilner], End of Religious Controversy, 41-55.

80. M[ilner], End of Religious Controversy, 78-115.

81. M[ilner], End of Religious Controversy, 117-236.

82. Others too singled out this matter as important in apologetic. The relevant material was republished separately in the form of cheap tracts for free distribution. See John Milner, Letters on the Rule of Faith: Or the Method of Finding the True Religion . . ., 3 parts (London: Catholic Institute of Great Britain, 1838-39). 
element in Catholic apologetics. It would have been familiar, for example, from Challoner's Grounds of the Old Religion. ${ }^{83}$ However, by making the matter fundamental and elaborating it in relation to the English Enlightenment, Milner brought a freshness to the field of controversy, the staleness of which was certainly not merely an attribution by Enlightenment prejudice. By his Letters to a Prebendary and, much more, by his End of Religious Controversy, he changed the orientation of Catholic apologetic. While his work served well the needs of those who were inclined or constrained by their opponents to labour with centuries-old themes in Catholic-Protestant polemic, it also offered new themes and an effective new approach, which went beyond the familiar tactic of exploiting Protestant divisions. It utilized, foundationally, the new convictions of the age about the Enlightenment, now exposed in all its falsity and malignancy by the Revolution. What was constructed was an assertion of Protestantism's essential identity with this evil, revealed by its history. The struggle to defend orthodoxy in the Church of England was thus pointless. No matter how far its defenders went in casting off the "holy alliance" between Anglican and Enlightenment thought ${ }^{84}$ the corruption would still be found. It was not that Milner was less anti-Protestant than his predecessors in controversy, distracted by more contemporary concerns. The struggle against Enlightenment and Protestantism were one and constituted a single orthodox cause.

Milner deserves credit for his originality in both his historical and his controversial work. However, a concern with periods rather than persons yields a preference for the typical rather than the singular individual and, indeed, Milner's claim to importance derives from his conformity to the ascending intellectual currents of the time. One would hardly wish to place him among the great reactionary figures who attempted the healing of Europe after the trauma of the Revolution. Yet in his attempts to expose the origins of the evil and make use of the resources of the past - and particularly the mediaeval past - he was conformed to them. The consistency with which he applied himself to this task, amidst the distractions of pastoral and political life, was remarkable. It is this consistency which makes Milner's life and thought, given a typological interpretation, a guide to the understanding of the Catholicism not only of his own period, but also of later ones.

83. Richard Challoner [A Convert, pseud.], The Grounds of the Old Religion... ([London]: n.p., 1742), 31-47.

84. For the concept of the "holy alliance," see J. Gascoigne, Cambridge in the Age of Enlightenment: Science, Religion and Politics from the Restoration to the French Revolution (Cambridge: Cambridge University Press, 1989). 